\title{
Trends in Higher Education: A view from abroad
}

(Editorial)

\author{
Prof. Trevor Hassall (t.hassall@shu.ac.uk) \\ Sheffield Hallam University (Sheffield, UK) \\ http://dx.doi.org/10.12795/EDUCADE.2012.i03.01
}

An important issue for accounting educators in the UK over the last two decades has been responding to the criticism levelled at the process and product of accounting education by potential and actual employers. The original criticism was the accounting students were not prepared for the workplace. A serious underlying criticism was that accounting students' knowledge was in the form of "knowing that" and insufficiently in the form of "knowing how". Students had knowledge of accounting and its processes but were unprepared to put that knowledge into practical use. These criticisms were predominantly voiced in the USA but were immediately followed by evidence of similar complaints from the UK, Australia, etc.

The focus quickly became on the balance between knowledge and vocational skills and personal qualities. It is interesting initially to review these two areas separately. Accounting knowledge in these decades underwent a series of major changes. The first was a volume effect. The volume of knowledge students were apparently required to know increased exponentially. A simple example can be found in the development of financial reporting standards. Originally there were a small number of domestic accounting standards this has through a series of iterations evolved into a considerable number of international accounting standards. This represents only one area of the knowledge domain, developments in taxation, corporate finance, management accounting, etc. have meant that the required knowledge content has increased substantially. One of the considerations that has not emerged and been seriously debated is the extent to which there should be reconsideration of the overall scope of the accounting education process. There is now, quite rightly a requirement from the International Federation of Accountants (IFAC) that accountants undertake continuing professional development (CPD). If we consider the Benner (1982) model of professional development, this visualises a progression from novice to expert. If knowledge is expanding exponentially at which point in this continuum should this new knowledge be integrated. 
Or more directly what can an accounting graduate be expected to know on graduation?

Secondly, a further question arises in respect of the way in which undergraduates might be expected to understand and interact with knowledge. The influence of information technology (IT) identified by Albrecht and Sack (2000) has meant a change in the way we store, access, and transmit information and knowledge. It has been suggested that modern students, in their increasing use of IT, interact with the knowledge base in a completely different way to their predecessors This change brought about by IT has also begun to change the way in which we teach accounting through computer based learning and virtual learning environments.

A criticism of traditional approaches to teaching accounting is that content based approaches encourage memorization and promote the idea that there is a right answer to every problem. Further that students they do not develop critical skills. This is supported by Wolcott et al. (2002) who suggest there is little empirical evidence that traditional pedagogic methods can enhance the critical thinking skills of accounting students. Consequently they also do not prepare students for the ambiguous business world that they will soon encounter (Adler et al. 2004). The business world is dynamic and is changing. The role of the accountant is also changing from the more traditional view as being the 'bean counter' to that of a broad market-orientated, business advisor and financial expert. This is shifting the core role of the accountant away from the preparation of accounts to that of interpreting and communicating them. IFAC (2002) recognized this change and commented "the role of accountants is moving from that of transaction manager to communicator and strategist". Harrington (2005) believes that in the future the role and contribution of accountants working in practice will continue to grow but only if they are able to meet the demands of the new environment by acquiring new skills and developing new products and services. IFAC (2002) has expressed the opinion that finance managers of the future will need to possess strong communication skills, the ability to interpret complex financial data and a broad knowledge of global economic markets and cultural issues.

In order to respond to the changing environment and to fulfil the expectations of employers, the specific needs of the employers must be identified. This process has been ongoing for many years. Professional and academic associations, predominantly in the USA, have through published reports and statements made public their views of the desired profile of a professional accountant. Perhaps the most consistent finding in these reports and statements is the increasing importance given to non-accounting capabilities and skills. Albrecht and Sack (2000) indicated that educators and practitioners agree on which skills are the most important: written communications, analytical/critical thinking and oral communications. It is somewhat surprising that despite all of the above research and the resulting identification of key communication skills and competencies that needed to be developed (validated by the consensus between academics, employers and the accounting profession) that current research suggests that the levels of competences exhibited in the work place are still a major cause of concern. The accounting curriculum was under pressure in both areas of knowledge and skills with pressure to increase in the accounting curriculum the volume and intensity of both areas. An interesting observation is that during this period accounting educators were expected to incorporate extended knowledge and vocational skills into the curriculum but there was little or no discussion of resources or even the potential for increased resources to facilitate these changes.

This situation has changed dramatically. The worldwide recession has meant that in nearly every country that resources allocated to universities have been subjected to review. In the UK the Government has responded by drastically cutting funds allocated to universities, but allowing universities to raise fees from students. I am sure that many 
foreign governments are watching this experiment with interest as it could facilitate the opportunity to reduce government borrowing and budget deficits. From September 2012 students attending UK universities will pay tuition fees of on average $£ 8,500$ a year (approximately $10,500 €$ ). For a three year accounting degree this will total a minimum of $£ 25,500$ or $31,500 €$. This change may mean a substantial change in the nature of the relationship between academics and their students. Academics in the UK are being encouraged to view students as customers.

Universities have often followed management trends developed in commercial environments. An example is the concept of quality as a performance measure. Various approaches to quality have been developed but perhaps the most often quoted is "fitness for purpose". A logical progression from this is to establish "whose purpose" or who is the customer? This raises a very interesting question for education. Is it the student, could it be the employer, or is it the society who funds the university. The recent changes in the UK bring this into sharp focus because the broader society's role as the primary funder has been replaced by the direct funding supplied by the student.

Student expectations can therefore be expected to change. Previously they have graduated with in our case an accounting degree. Now they will graduate with an accounting degree and a substantial debt that at some point will need to be repaid. Therefore a major requirement of the students will be the ability to gain employment and facilitate the repayment of this debt. So the requirements of students and their potential employers will be that students are employable. Increasingly then a new phrase has emerged as the ultimate requirement for this new set of students, "employability".

In the UK employers report that even during the recession graduate jobs in the accounting and finance sector have remained unfilled. The employers state that they could not find graduates of sufficient quality and that this is because the applicants lacked the basic skills needed for employment. So we return again to the employer requirements necessary for development of accounting graduates which are vocational and personal skills. These are now matched by the students' requirements for employability. Can traditional approaches to the teaching of accounting fulfil this, probably not? If we in the UK are to deliver these changed circumstances we may need to recognise these momentous changes and to react to them. We have for many years had a queve of students waiting to enter university each year. A failure to meet their needs and expectations may in future mean that the number of students wishing to enter university each year may reduce and alternatives to university education may emerge. Large companies and auditing practices may develop their own education and training schemes. In fact, if we as accounting academics are to survive change may not be an option it may be a necessity.

Sheffield, 18-December-2012 


\section{References:}

ADLER, R. W., WHITING, R.H. Y WYNN-WILLIAMS, K. (2004): Student-led and teacher-led case presentations: empirical evidence about learning styles in an accounting course. Accounting Education, 13(2): 213-229.

ALBRECHT, W.S. Y SACK, R.J. (2000): Accounting Education: Charting the Course through a Perilous Future. Accounting Education Series, Volume 16, American Accounting Association.

BENNER, P. (1982): From novice to expert. American Journal of Nursing, 82(3): 402-407.

HARRINGTON, C. (2005): The Accounting Profession: Looking Ahead. Journal of Accountancy, 200(4): 43-48.

InTERnAtIONAL FEDERATION OF ACCOUNTANTS - FinANCIAL AND MANAGEMENT ACCOUNTING COMMITteE (2002): The Role of the Chief Financial Officer in 2010. New York: IFAC.

Wolcott, S. K., Baril, C. P. Cunningham, B. M., Fordham, D. R. y St. PIerRe, K. (2002): Critical Thought on Critical Thinking Research. Journal of Accounting Education, 20(2): 85-103. 